\title{
Storm-wave development of shore-normal grooves (gutters) \\ on a steep sandstone beach face
}

\author{
Paul Carling ${ }^{1,2}$ *, Jon Williams ${ }^{3}$, Julian Leyland ${ }^{1}$, Luciana Esteves ${ }^{4}$ \\ ${ }^{1}$ Geography and Environment, University of Southampton, Southampton, UK; \\ ${ }^{2}$ College of Environment and Planning, Henan University, Kaifeng, Henan Province, \\ 475004, China
}

${ }^{3}$ Mott MacDonald, Croydon, UK

${ }^{4}$ Bournemouth University, Talbot Campus, Poole, Dorset, UK.

${ }^{*}$ Corresponding author: P.A.Carling@soton.ac.uk

\begin{abstract}
Shore-normal grooves (gutters) cut into the seabed have been reported widely from the marine geological record. Grooves commonly are spaced regularly across plane, consolidated surfaces in the littoral and sub-littoral zones and may be deeply incised.

Despite their common occurrence in the rock record, there are few detailed descriptions of examples from modern environments. Previously reported examples have been ascribed to erosion by wave-induced currents, especially storm-driven near-shore flows. In particular, examples from beach faces have been related to either wave swash or backwash. However, no conceptual model exists to explain the presence of grooves, their morphology or their spacing alongshore.
\end{abstract}

Herein, quasi-regularly spaced grooves on a soft sandstone beach face are described and interpreted to have formed due to wave breaking and swash zone processes consequent upon exceptional storms at sea. The groove morphologies are quantified using terrestrial laser scanning. Numerical modelling of the translation from offshore waves to nearshore breaking waves provides estimates of the swash zone parameters. A consideration of swash zone processes provides an explanation for formation of the grooves. In particular, the 
swash zone shear stress distribution and consequent bed erosion is a dome-shaped function of distance across the beach face, and this controls the cross-shore variability in groove depths. High-speed sheet flows, such as swash and backwash, develop periodic, shore normal, high and low speed streaks alongshore. Consequent streaky erosion produces the quasi-regular alongshore groove spacings. However, on any given beach face the specific spacing of grooves is likely a property, not only of the local sheet flow attributes, but also of larger-scale morphological forcing. This outcome suggests that spacing is an emergent property of the coupled sheet flow and larger-scale forcing, and thus specific spacings on any beach face remain unpredictable.

\section{Key Words}

Gutter-casts, gutters, runnels, beach slope, wave processes on beaches, wave scouring, UK, Medmerry

\section{Introduction}

Linear erosional bedforms cut into soft bedrock have been reported widely from the marine geological record, albeit with different descriptive names (e.g. furrows, grooves, gutters, runnels). The terms 'groove-cast' or 'gutter-cast' have been applied widely to the sedimentary fill within reported examples (e.g. Birkenmajer, 1958; Whittaker, 1973; Myrow, 1992a). The bedforms are usually relatively long, straight or weakly sinuous but otherwise parallel (Allen, 1982), and spaced more-or-less regularly across fairly plane surfaces at intervals of a few decimetres to a few metres. The incisions may be deep $(<1 \mathrm{~m})$ with vertical and overhanging sides (Plint, 1991; Plint \& Norris, 1991; Myrow, 1992; McKie, 1994; Plint \& Nummedal, 2000; Plint \& Cheadle, 2015). Plint \& Norris (1991) and Shank \& Plint (2013) loosely apply the term 'gutter' to offshore examples and the term 'groove' to nearshore examples. Consequently, the term groove is adopted in the following text. In the littoral geological record, grooves are usually shore-normal (Plint \& Norris 1991; Plint \& Nummedal, 2000) and have been ascribed to erosion of the substratum by reversing waveinduced currents (Plint \& Norris, 1991; Duke, 1990; Beukes, 1996), especially during storms 
61 (Hiscott, 1981; Plint, 1991; Plint \& Nummedal, 2000). Similarly, Aigner (1985) invoked reversing flows as the formation mechanism for sub-littoral grooves that he hypothesized were due to storm wave-induced return-flows. Thus, these various grooves are believed to align roughly parallel to wave swash, backwash or surf currents.

\subsection{Study site at Medmerry, south coast of England}

Despite their common occurrence in the rock record, grooves can have disparate origins (Myrow, 1994) and so it is important for environmental reconstruction to detail modern examples to aid discrimination of the depositional context. In the case of modern beaches, there are relatively few published examples and all are developed on consolidated substrata (soft bedrock) within littoral and sub-littoral locations subject to variable wave-energy levels (e.g. Groba, 1959; Seibold, 1963). Grooves are usually less than a metre apart and less than a metre deep (e.g. Plint, 1991; Plint \& Nummedal, 2000). Allen (1982) and Otvos (1999) report examples of erosional grooves with spacings of $1 \mathrm{~m}$ or less from both modern and ancient beach faces that are ascribed to wave swash, whereas Evans (1938) and Hawkes (1962) related such features to backwash. Allen (1982) was unable to account for the spacing of the beach face grooves, which he inferred was due to concentration of swash into shore-normal parallel zones. Shank \& Plint (2013) illustrate elongate grooves on nearshore ravinement surfaces cut in sandstone and mudstone; these may have steep, vertical or overhanging margins, but these grooves do not appear to exhibit a regular longshore spacing.

Herein, grooves are reported that were observed in soft sandstone on a steep beach face, which was exposed by storm wave action stripping the overlying shingle (flattened pebble layer). The beach is at Medmerry, in southern England (Fig. 1). Although no hydrodynamic data were collected during the event, simulations of wave run-up on the beach face for known offshore conditions are placed within a theoretical framework and are used to propose a model for groove formation. This framework is used to test the hypothesis that groove morphology reflects the beach face wave-induced sheet flow processes within the swash zone. 
91 An aerial view of the study area from the Channel Coastal Observatory (CCO; www.channelcoast.org) from July 2014 shows the site after the winter storms of 2013-2014

\section{A}

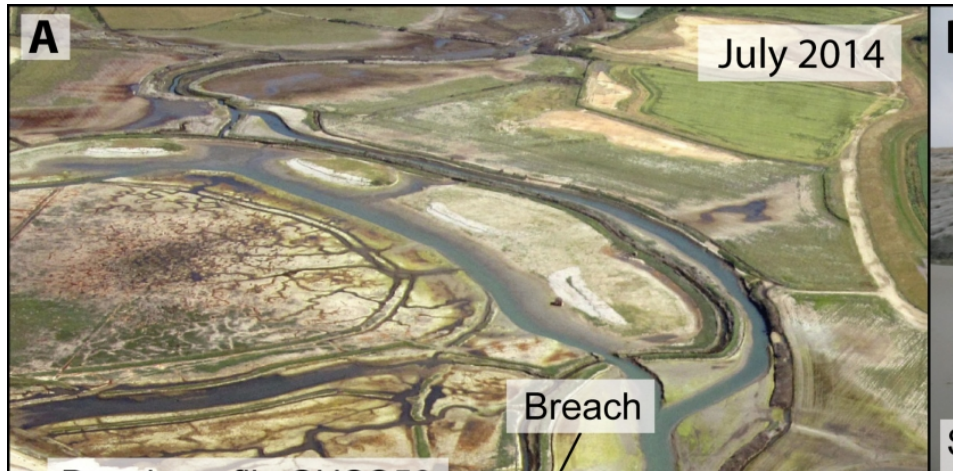

B

Beach profile SUSS53

Figure 1: A) Aerial view looking to the north of the Environment Agency Medmerry managed realignment breach site, July, 2014 (CCO), showing the location of the study site (circa N $\left.50^{\circ} 44^{\prime} 30.70^{\prime \prime} ; 0^{\circ} 49^{\prime} 19.26^{\prime \prime}\right)$ and beach profile used in the modelling. Inset (B) shows the study area and grooves being laser scanned (see Method).

\subsubsection{Geology of the Medmerry beach face}

The Medmerry foreshore consists of soft sandstone in three formations of the Eocene Bracklesham Group shallow marine deposits, with a thin covering of shingle. These brackish-water deposits constitute primarily of glauconitic, fine to medium, thick-bedded sandstone rich in clay and silt. They contain marine shells, specifically Ostrea and large 
Pholas crispate (L.). Several accounts provide detail of the Bracklesham Group (Curry et al., 1977; Edwards \& Freshney, 1987; Plint, 1988; Bone \& Tracey, 1996; King, 1996; Daley, 1999; Aldiss, 2002) but here the formation nomenclature of Curry et al. (1977) is adopted. The lower Wittering Formation (Units W7 - W9: Curry et al., 1977; Plint, 1988) is rarely exposed, whereas the beach face exposes circa $8 m$ thickness of the Earnley Formation (Units E9-E12: Curry et al., 1977). The upper foreshore (shorewards of the gravel overwash - Fig. 1) consists predominately of the Selsey Formation (Units S4-S7: Curry et al., 1977).

The shoreline has been retreating throughout the late $19^{\text {th }} \mathrm{C}$ and $20^{\text {th }} \mathrm{C}$ at around $1 \mathrm{~m}$ per year, but the sandstone usually is exposed only locally as a steep slope $(S \sim 0.10)$, largely because it is overlain by a variable thickness of modern shingle with sand cover to seaward on the lower beach face. The shingle cover rises to circa $5.4 \mathrm{~m}$ Ordnance Datum. During high tides both plunging and surging waves can occur on the shingle, but at low tides the low gradient offshore sandy beach is subject to gently spilling waves. In calm seas, waves

\subsubsection{Hydrodynamics of the Medmerry area}

The Medmerry shore faces Bracklesham Bay and the English Channel. Detail of the marine environment of the bay largely is recorded in grey literature summarized by the SCOPAC database (http://www.scopac.org.uk/scopac_sedimentdb/epag/epag.htm - Accessed 21 
January 2018). The spring and neap tidal ranges are about $4.9 \mathrm{~m}$ and $2.7 \mathrm{~m}$, respectively, at Pagham Harbour and at the entrance to Chichester Harbour to the east of the study area.

140 The offshore tidal currents at Medmerry flow predominantly eastwards and southeastwards. The offshore wave climate is dominated by waves from the south and southwest, with episodes of less energetic waves from the southeast. This wave orientation, along with minor refraction, results in wave crests that are frequently parallel to the nearshore bathymetric contours and the Medmerry beach face. Met Office WaveWatch hindcast wave model data predict that the maximum annual significant wave height $\left(H_{s}\right)$ offshore from Medmerry is $3.87 \mathrm{~m}$ in water depths of the order of $15-20 \mathrm{~m}$. Maximum significant wave heights $\left(H_{s}\right)$ are substantially greater than this, on the order of $15-20 \mathrm{~m}$ for offshore waves $2 \mathrm{~km}$ to the east, $3.87 \mathrm{~m}$ at Medmerry, and $4.32 \mathrm{~m} 7 \mathrm{~km}$ to the west.

\subsubsection{Synoptic storm weather and sea state conditions}

From mid-December to February 2013/2014, the UK experienced a period of extreme weather as a series of major winter storms affected the south coast of England (The Met. Office, 2014; Masselink et al., 2015). These storms were characterised by a combination of large wind-generated and swell waves and some occurred during high spring tides. Winds of 60 to $70 \mathrm{kt}\left(130 \mathrm{~km} \mathrm{~h}^{-1}\right)$, with gusts of $92 \mathrm{kt}\left(170 \mathrm{~km} \mathrm{~h}^{-1}\right)$ occurred at Needles Old Battery (Isle of Wight) $54 \mathrm{~km}$ to the west of Medmerry. Exceptionally high near-shore wind waves $(H \approx 6 \mathrm{~m})$ were recorded for the south coast beaches on the $5^{\text {th }}$ January 2014 , and these storm conditions persisted periodically through to mid-February 2014 (Bradbury \& Mason, 2014). The later storms from early- to mid-February 2014 were much more severe. Overall, there were at least 12 major winter storms during the period from mid-December 2013 to mid-February 2014, one of the stormiest period of weather the UK has experienced for 20 years. These were evidently severe storms, but considered individually other more severe singular events have occurred in recent years. However, it was exceptional for such a rapid succession of storms to occur in such a short period 
1682 Method

169

\subsection{Wave modelling}

The primary objective of the modelling study described here is to simulate the wave conditions on the Medmerry shoreface during storm conditions described above. It is argued that since infragravity wave motion dominates the inner surf and swash zone on sandy beaches, it is also the primary control of morphological evolution. The XBeach morphodynamic model has been developed on this premise (vis Roelvink et al., 2009). However, because the gradient of gravel beaches is typically much steeper than sandy beaches, swash motion at incident wave frequencies is dominant and infragravity wave motion is of secondary importance. Further, the hydraulic conductivity of gravel is at least an order of magnitude higher than for sand and thus interactions between swash flows and the beach groundwater table are important controls of the hydrodynamics and the morphological response of the beach to waves until, as in the present application, the shingle it stripped to the bedrock. Consequently, the XBeach-G (http://oss.deltares.nl/web/xbeach/home) variant model has been developed to simulate gravel beach processes (McCall et al., 2014; 2015). This model is used in the present study to estimate hydrodynamic and wave conditions of several storm events that occurred during the winter of 2013-2014.

XBeach-G solves wave-by-wave flow and surface elevation variations due to short waves in intermediate and shallow water depths using a one-layer, depth-averaged, non-hydrostatic extension to the XBeach model. In many respects XBeach-G is similar to the SWASH model (Zijlema et al., 2011). To account correctly for upper swash infiltration losses and exfiltration effects on lower swash hydrodynamics on gravel beaches, XBeach-G also computes groundwater dynamics and the exchange between groundwater and surface water using the XBeach groundwater model.

In building the model, the objective was to reproduce as accurately as possible with available data, the pre-storm and post-storm beach profiles, and to link these seamlessly 
with the offshore bathymetry. Swath bathymetry for the area from 2013, the location of the Bracklesham Bay wave buoy, the approximate location of mean high water spring tide 197 level (MHWS), and the Medmerry breach are all known inputs (Fig. 2). The offshore bathymetry is from a tidally-corrected multi-beam survey (CCO). The data were resampled and smoothed in GIS to give a horizontal and vertical resolution of $2 \mathrm{~m}$ and $0.2 \mathrm{~m}$, respectively. The data were further re-sampled to create the XBeach-G model grid using a variable resolution that provided the highest resolution over regions of the profile with the steepest gradients. This procedure provided a maximum horizontal resolution of $0.5 \mathrm{~m}$ in the nearshore, increasing to a maximum value of $5 \mathrm{~m}$ in the flatter, offshore areas. The maximum and minimum measured offshore water depth are approximately $-16 \mathrm{~m}$ and $1 \mathrm{~m}$ Ordnance Datum Newlyn (ODN), respectively.

206

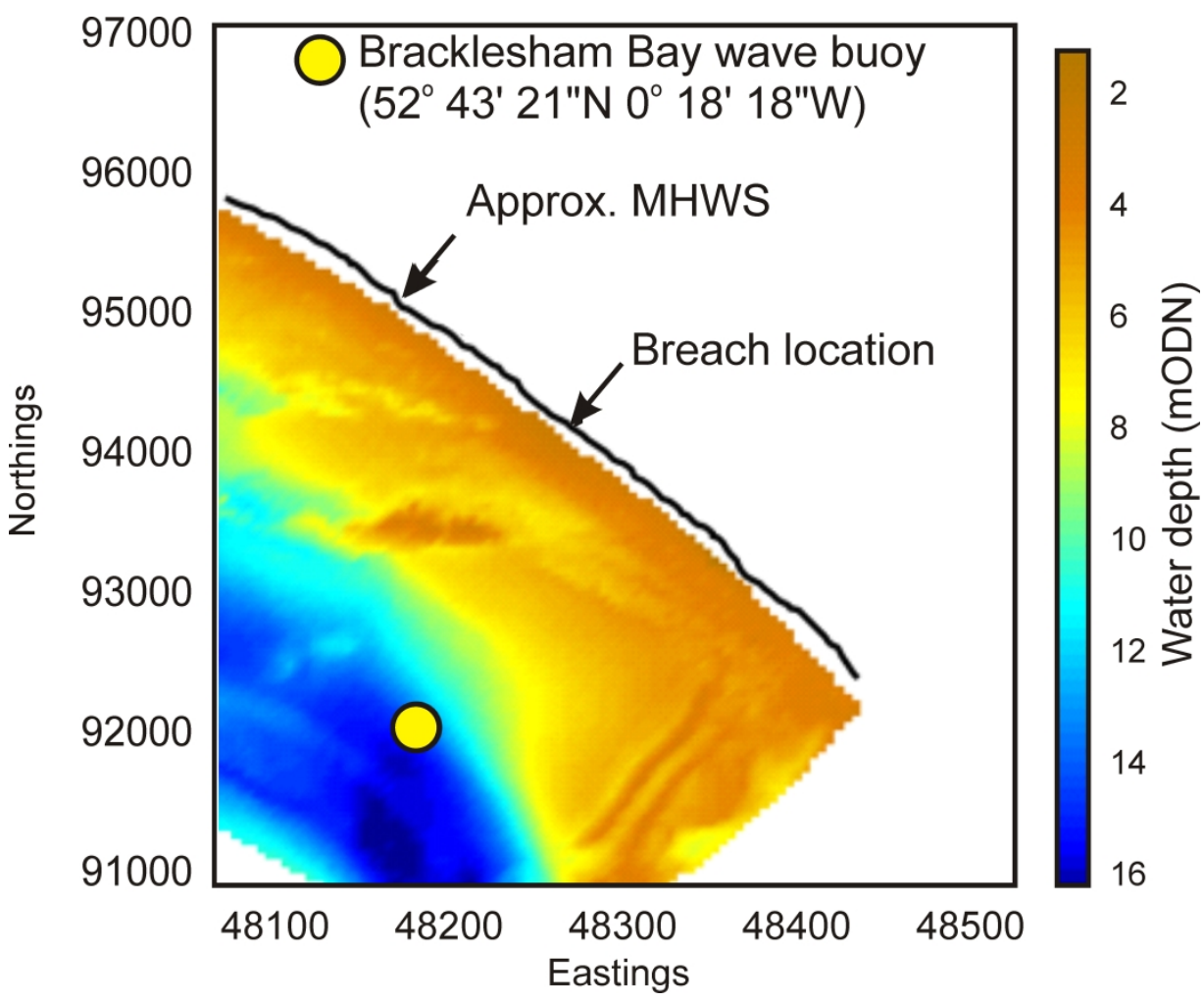

208

209 Figure 2: Swath bathymetry from 2013 showing the location of the Bracklesham Bay wave 210 buoy (CCO), MHWS and the Medmerry breach. 
212 The impact of the 2013-2014 winter storms is evident on beach profile SUSS56 measured on 24th September 2013 before the start of the winter storms, and 1 May 2014 after the

214 winter storms (Fig. 3; location is shown in Fig. 1A). The elevation of mean high water

215 (MHW) and mean low water (MLW) measured at Portsmouth is also noted (Fig. 1A).

216 Subsequently, these profiles are referred to here as the pre-storm and post-storm beach

217 profile, respectively.

218 Like the adjacent beach profiles SUSS53 and SUSS58 (Fig. 1), profile SUSS56 (Fig. 3) was

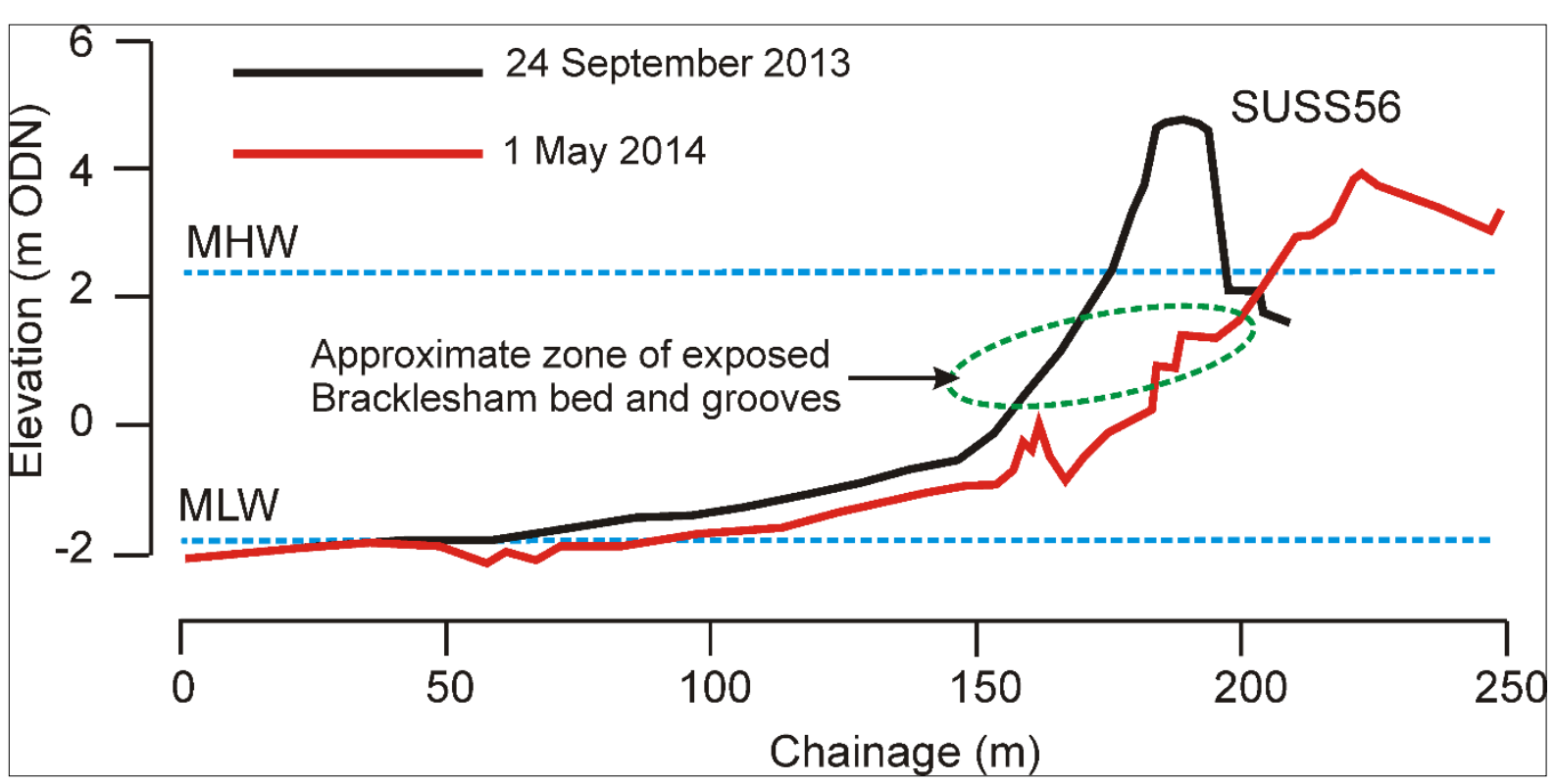

228

Figure 3: Pre-storm and post-storm beach profile SUSS56 showing MHW and MLW

229 (Portsmouth) (CCO). subjected to severe erosion during the period 24 September 2013 to 1 May, 2014 with a landward recession of $\sim 25 \mathrm{~m}$ and crest lowering of $1.5 \mathrm{~m}$. However, near the location of MLW, the beach elevation showed much less change (typically $<0.2 \mathrm{~m}$ ). Significantly, the thin gravel deposits normally present on the beach face along this frontage were removed, in part transported landwards to form a series of overwash fan deposits. The removal of the sediment resulted in the exposure of the Earnley Formation to tidal and wave action. A site visit in July 2016 showed that the overwash deposits have remained in situ since the storms of 2013-14 and the Earnley Formation remained exposed. 
569

570

571

572

573

574

575

576

577

578

579

580

581

582

583

584

585

586

587 
232 To ensure wave transformations are correctly simulated in the model, the XBeach-G model

233 bathymetry and topography were created by extending profile SUSS56 offshore onto the

234 bathymetry to the Bracklesham Bay wave buoy location (Fig. 2) and extracting the profile

235 data at $5 \mathrm{~m}$ intervals to produce a seamless 1D XBeach model profile extending for

236 approximately $3000 \mathrm{~m}$ from an offshore location around $-15 \mathrm{~m}$ ODN to the beach crest at

237 around $5 \mathrm{~m}$ ODN (Fig. 3). Because the evolving characteristics of the beach profile during the

238 period between surveys is unknown, for the purpose of the modelling study only the pre-

239 storm profiles are used.

240 Tide and wave conditions during the exceptionally stormy winter period from 1 December

2412013 to 10 February 2014 are shown in Fig. 4. The tidal data comes from the Class 'A' tide

242 gauge at Portsmouth

243 (https://www.bodc.ac.uk/data/hosted_data_systems/sea_level/uk_tide_gauge_network/

244 - Accessed 22 January 2018) and includes astronomical and meteorological components.

245 Wave data from the Bracklesham Bay wave buoy (Fig. 2) were obtained from the CCO.

246 While the exact times and characteristics of the events resulting in severe beach erosion

247 and the creation of grooves are unknown, it is possible to quantify a number of key

248 hydrodynamic and wave parameters that characterized selected storm events. In this way

249 an assessment can be made that links the local, near-shore wave and hydrodynamic

250 conditions during storm events with the grooves, and thus further our understanding of

251 their origin and formation. 

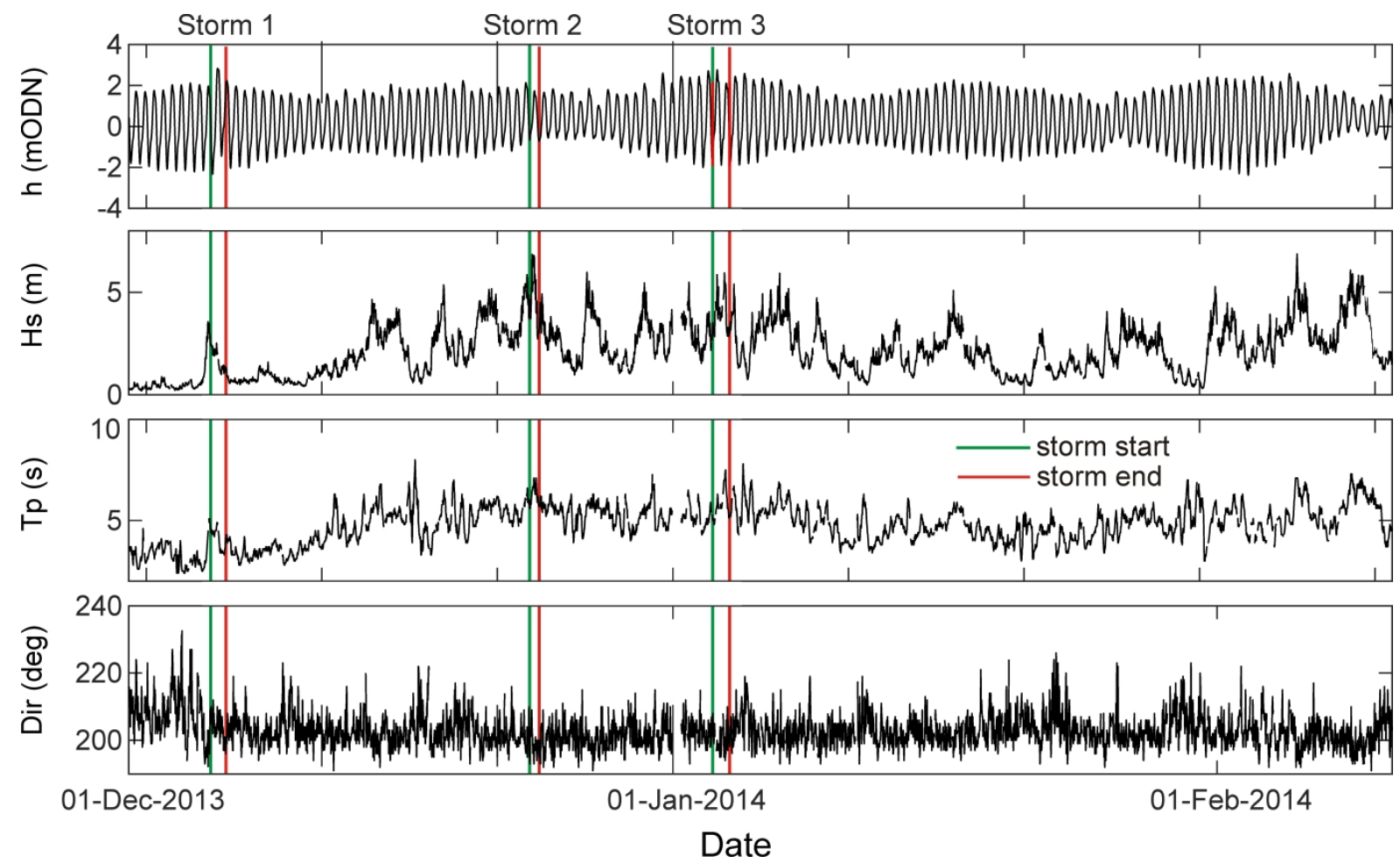

254 Figure 4: Tide and wave conditions 1 December 2013 to 10 February 2014 showing the three storm periods simulated in the XBeach-G models (CCO). Red stars represent the start and end of the three storm events modelled. $h$ - tide elevation; Hs - significant wave height ; Tp - peak wave period; Dir - mean wave direction.

258

259 Three storm periods were identified that provide a range of extreme events that typify the conditions during the 2013-2014 winter period (Fig. 4): (a) Storm 1 with moderate waves coincident with an exceptionally high tide; (b)

(b) Storm 2 with exceptionally high waves occurring during neap tides; and (c) Storm 3 with high waves occurring during spring tides. The characteristics of these storms (Fig. 5, Table 1) include minimum, maximum and average 264 values for tidal elevation, $h$; significant wave height, $\mathrm{Hs}$; peak wave period, $\mathrm{Tp}$; and mean wave direction, Dir; for each of the three storm events (Fig. 4). 
Storm 1
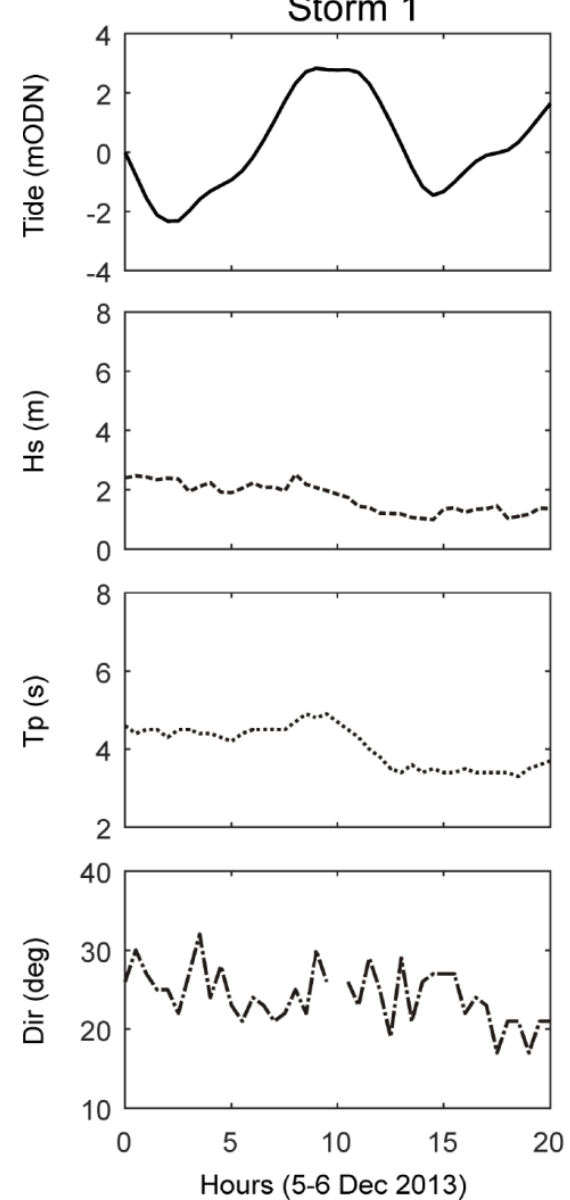

Storm 2
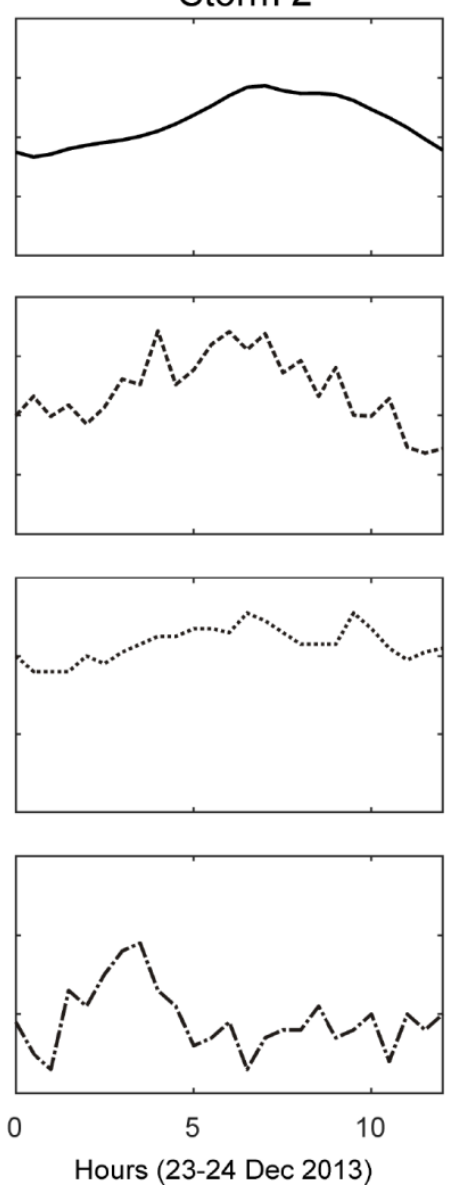

Storm 3
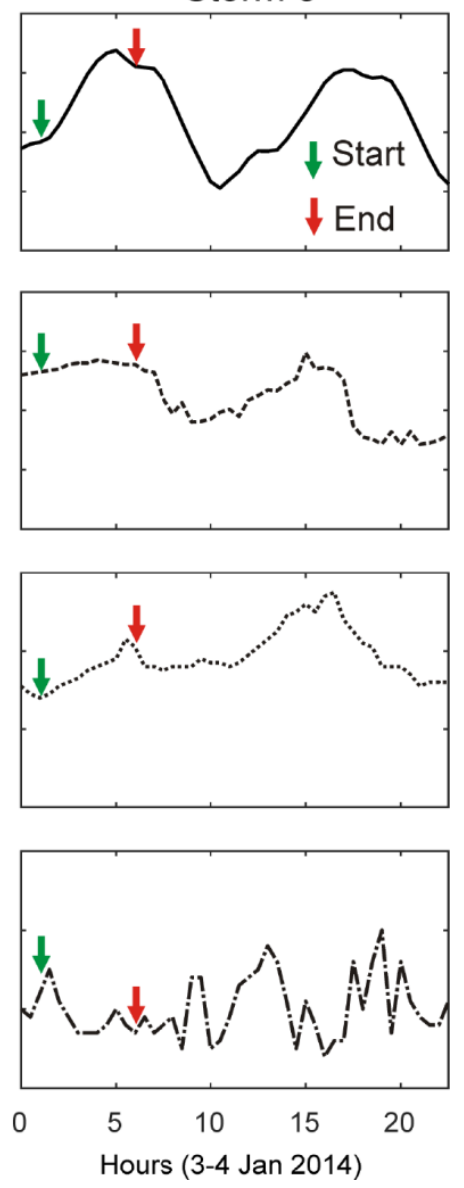

267 Figure 5: Tide and wave conditions during the three storm periods simulated in the XBeach$268 \mathrm{G}$ models (CCO). $h$ - tide elevation; Hs - significant wave height ; Tp - peak wave period; Dir $269-$ mean wave direction.

271 Table 1: Characteristics of the three storm events selected for the study at the Bracklesham 272 wave buoy $5 \mathrm{~km}$ offshore. 
For a given storm period, the water elevation time-series (Fig. 5) was applied at the offshore

275 boundary of the model. Offshore wave conditions during each storm (Fig. 5) were implemented as time-varying JONSWAP spectra, also at the offshore boundary. The crossshore boundaries were open and the beach was defined as being reflective. The median grain size of the beach sediment was set to $10 \mathrm{~mm}$ and other model parameters settings followed the fully validated XBeach 'factory' setting detailed in Deltares (2015). All XBeachG outputs were sampled at $1 \mathrm{~s}$ intervals.

\subsection{Terrestrial laser scanning of groove morphology}

On 29th January 2014 a Leica P20 Terrestrial Laser Scanner (TLS) was deployed during low tide on the lower sandy foreshore, looking up the beach towards the grooves (Fig 1B; Fig. 6). A single scan of the grooves over an area of approximately $10 \times 10 \mathrm{~m}$ was made using a point spacing of $3.1 \mathrm{~mm}$ at a $10 \mathrm{~m}$ distance, with a quality setting of 4 (the highest possible setting on the P20). These settings resulted in a mean point spacing of $\sim 2 \mathrm{~mm}$ and a mean point density of $\sim 2 \mathrm{M}$ points per $\mathrm{m}^{2}$. Due to poor weather, only one scan was collected, resulting in a few of the very deepest parts of the grooves oblique to the TLS location being occluded. The resulting point cloud required no cleaning or filtering and was processed using CloudCompare software (EDF R\&D, Telecom Paris, 2015. CloudCompare (Version 2.6.0) GPL Software. http://www.danielgm.net/cc/ - Accessed: 3 February 2015) to derive point cloud density estimates. The point cloud was cropped to a $4.3 \times 10 \mathrm{~m}$ area directly in front of the TLS instrument to allow more accurate estimates of runnel depths to be derived in the areas with least occlusion. The data were imported into ArcGIS and interpolated to form a surface using Delaunay triangulation. A series of 11 equidistantly spaced transects, perpendicular to the orientation of the grooves, were established across the surface at 0.9 $\mathrm{m}$ spacing to extract the underlying topographic data. The resultant profiles of ridge-groove features were analysed to derive metrics of groove spacing and groove depth. 


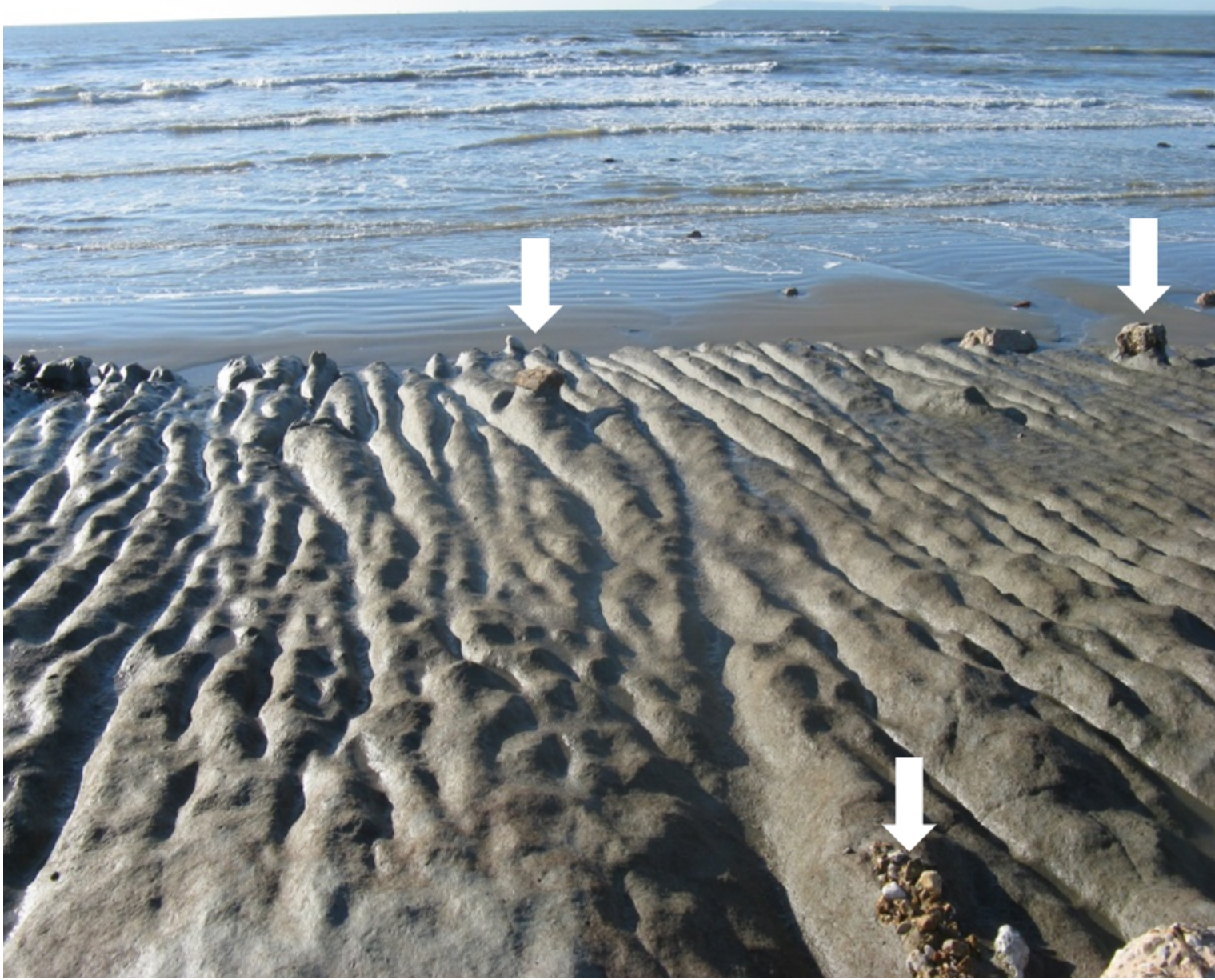

301 Figure 6: View to seaward from the top of a portion of the grooved beach-face in the general area surveyed using a Leica P20 Terrestrial Laser Scanner. Remnants of shingle cover remain as isolated blocks (two examples arrowed at the top of the photo) or small groups of pebbles (arrowed lower right). Field of view approximately $8 m$ to seaward.

\section{$3 \quad$ Results}

\subsection{XBeach-G modelling}

Because the hypothesis for groove formation proposed here is predicated on erosion by incident waves, the analysis of XBeach-G results for this study has focussed on predicted peak and time-averaged bed shear stresses at cross-shore locations on the beach face. To examine this hypothesis XBeach-G was run for each of the three storm periods (Fig. 5). Typifying results from all XBeach-G model runs, and thus providing a useful example with which to demonstrate how the model results support the groove formation hypothesis, XBeach-G results from the first 6 hours of the Storm 3 simulation (indicated in Fig. 5), 
314 hereafter termed $\mathrm{S}_{6}$ (Fig. 7A), which includes a rising spring tide plus surge in the range -

$3150.55 \mathrm{~m}$ to $2.76 \mathrm{~m}$ ODN and offshore significant wave heights and peak wave periods in the 316 ranges $5.2 \mathrm{~m}$ to $5.7 \mathrm{~m}$ and $4.9 \mathrm{~s}$ to $6.3 \mathrm{~s}$, respectively. Wave-induced cross-shore flow 317 velocity time-series spanning approximately 6 hours were extracted from XBeach-G output 318 for $\mathrm{S}_{6}$ at 12 cross-shore locations on the beach face (Fig. 7B).
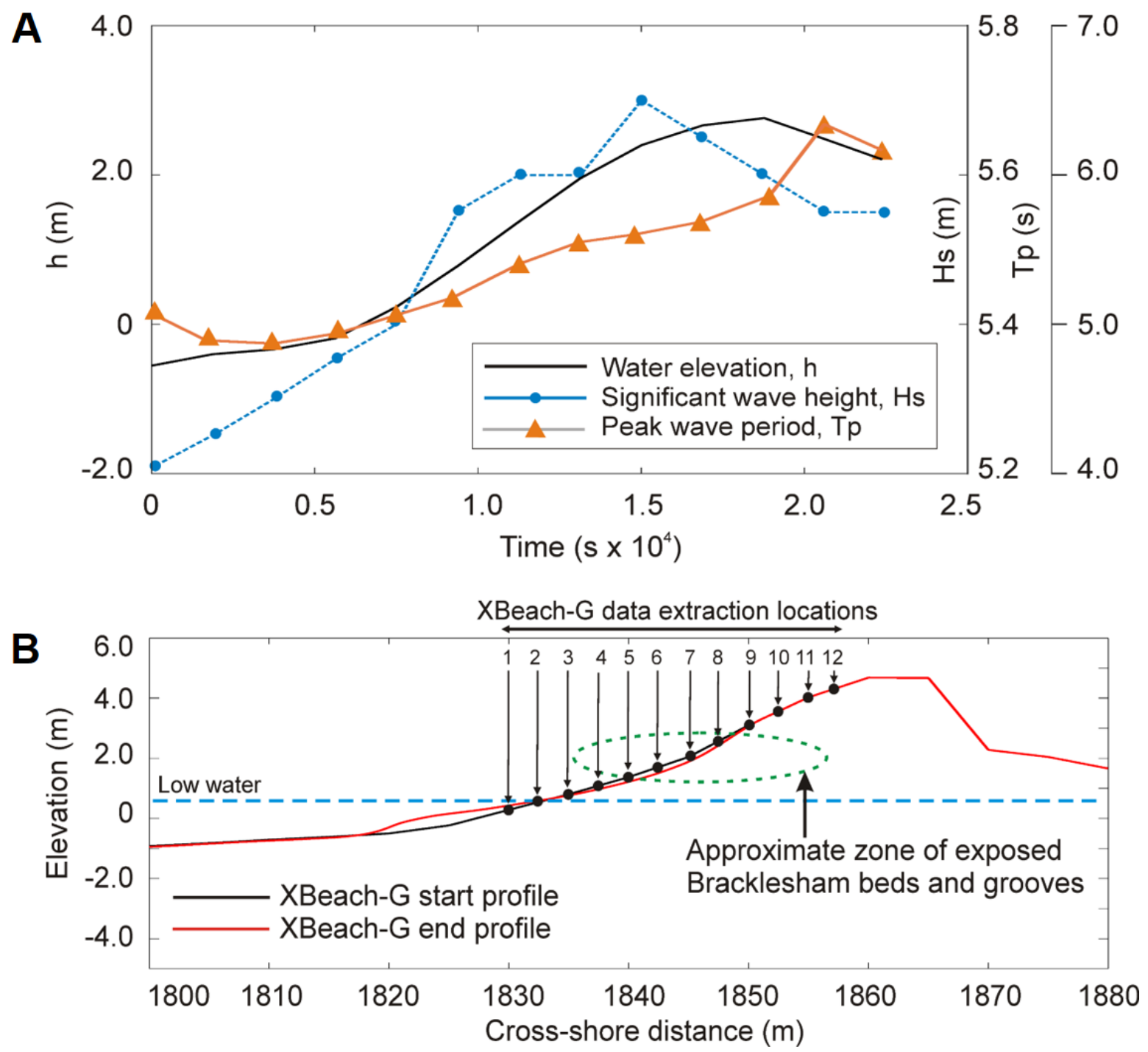

320 Figure 7: A) Hydrodynamic and wave conditions during storm period S36 (Fig. 5). B) Location 321 of XBeach-G data extraction points (1-12) at $2.6 \mathrm{~m}$ spacing between cross-shore distances 322 from $1830 \mathrm{~m}$ to $1857.5 \mathrm{~m}$. The black and red lines denote the beach profile at the start and 323 end of the XBeach-G simulation, respectively.

Table 2: Summary of key modelled parameters for Storm 3 swash zone around high water. 
326 Average swash zone water depths represent both swash and backwash events.

\begin{tabular}{|l|l|l|l|}
\hline $\begin{array}{l}\text { Wave } \\
\text { height } \\
40 \mathrm{~m} \\
\text { offshore } \\
(\mathrm{m})\end{array}$ & $\begin{array}{l}\text { Range of } \\
\text { nearshore } \\
\text { breaker } \\
\text { heights } \\
(\mathrm{m})\end{array}$ & $\begin{array}{l}\text { Average } \\
\text { swash } \\
\text { zone } \\
\text { depth } \\
(\mathrm{m})\end{array}$ & $\begin{array}{l}\text { Average } \\
\text { runup } \\
\text { velocity } \\
\left(\mathrm{m} \mathrm{s}^{-1}\right)\end{array}$ \\
\hline 0.50 & $1.25-1.50$ & 0.05 & 3.9 \\
\hline 0.65 & $1.50-1.75$ & 0.07 & 3.1 \\
\hline 0.80 & $1.75-2.00$ & 0.05 & 4.8 \\
\hline 0.95 & $2.00-2.25$ & 0.17 & 5.2 \\
\hline 1.10 & $2.25-2.50$ & 0.27 & 5.1 \\
\hline 1.25 & $2.50-2.75$ & 0.20 & 6.3 \\
\hline 1.40 & $2.75-3.00$ & 0.20 & 5.2 \\
\hline 1.55 & $3.00-3.25$ & 0.26 & 5.1 \\
\hline 1.70 & $3.25-3.50$ & 0.25 & 6.2 \\
\hline 1.85 & $3.50-3.75$ & 0.30 & 6.3 \\
\hline 2.00 & $3.75-4.00$ & 0.34 & 6.3 \\
\hline 2.15 & $4.00-4.25$ & 0.35 & 6.2 \\
\hline & & & \\
\hline
\end{tabular}

328 Individual swash and backwash events associated with incident waves were identified in the 329 time-series using a zero down-crossing time-series analysis routine with mean swash 330 velocities $(\bar{U})$ of around $2 \mathrm{~m} \mathrm{~s}^{-1}$ with instantaneous swash velocities peaking at around $5 \mathrm{~m} \mathrm{~s}^{-1}$ 331 during high-tides with swash zone water depths up to $0.35 \mathrm{~m}$ deep (Table 2). By assuming a 332 constant drag coefficient, $C_{d}$, of 0.0025 , the time-averaged bed shear stress was obtained 333 using the quadratic stress law:

$$
\bar{\tau}=\rho_{w} C_{d} U^{2}
$$

for swash $\left(\tau_{s w}\right)$ and backwash $\left(\tau_{b w}\right)$ events, where $\rho_{w}$ is the assumed density of sea water $337\left(1023 \mathrm{~kg} / \mathrm{m}^{3}\right)$ and $U$ is the depth-averaged instantaneous flow velocity predicted by XBeach338 G. In the model positive and negative $U$ values denote swash and backwash flows, 339 respectively. While it could be argued that the chosen $C_{d}$ value is arbitrary, it is a value 
340 recommended by Soulsby (1997) in situations where no information is available, or where 341 only a rough estimate is required. Further, because an important aspect of the present 342 study is to establish the general characteristics of the cross-shore wave-induced bed shear 343 stress distribution and its relationship, if any, to the observed groove morphology, the use 344 of this $C_{d}$ value will not affect this spatial interpretation of the XBeach-G model results.

345 Twenty-second time-averaged bed shear stress time-series (Fig. 8) from S3 6 spanning 346 approximately 6 hours at five cross-shore locations (1, 3, 5, 7, and 9, Fig. 7B) were 347 generated. The grouped nature of the incident waves defined by the Jonswap spectra is 348 clearly evident. Moderate bed shear stress values $\mathrm{O}\left(4 \mathrm{~N} \mathrm{~m}^{-2}\right)$ occur first at the offshore 349 location 1 and, as the water level rises, subsequently decline to around $2 \mathrm{~N} \mathrm{~m}^{-2}$ as the zone 350 of breaking waves moves over and up the beach face. In this example and others, the 351 largest of the mean bed shear stresses $O\left(8 \mathrm{~N} \mathrm{~m}^{-2}\right)$ are related to locations on the beach 352 profile between sample locations 5 and 6 (Fig. 7B); this is the zone of the exposed 353 Bracklesham Group.

354

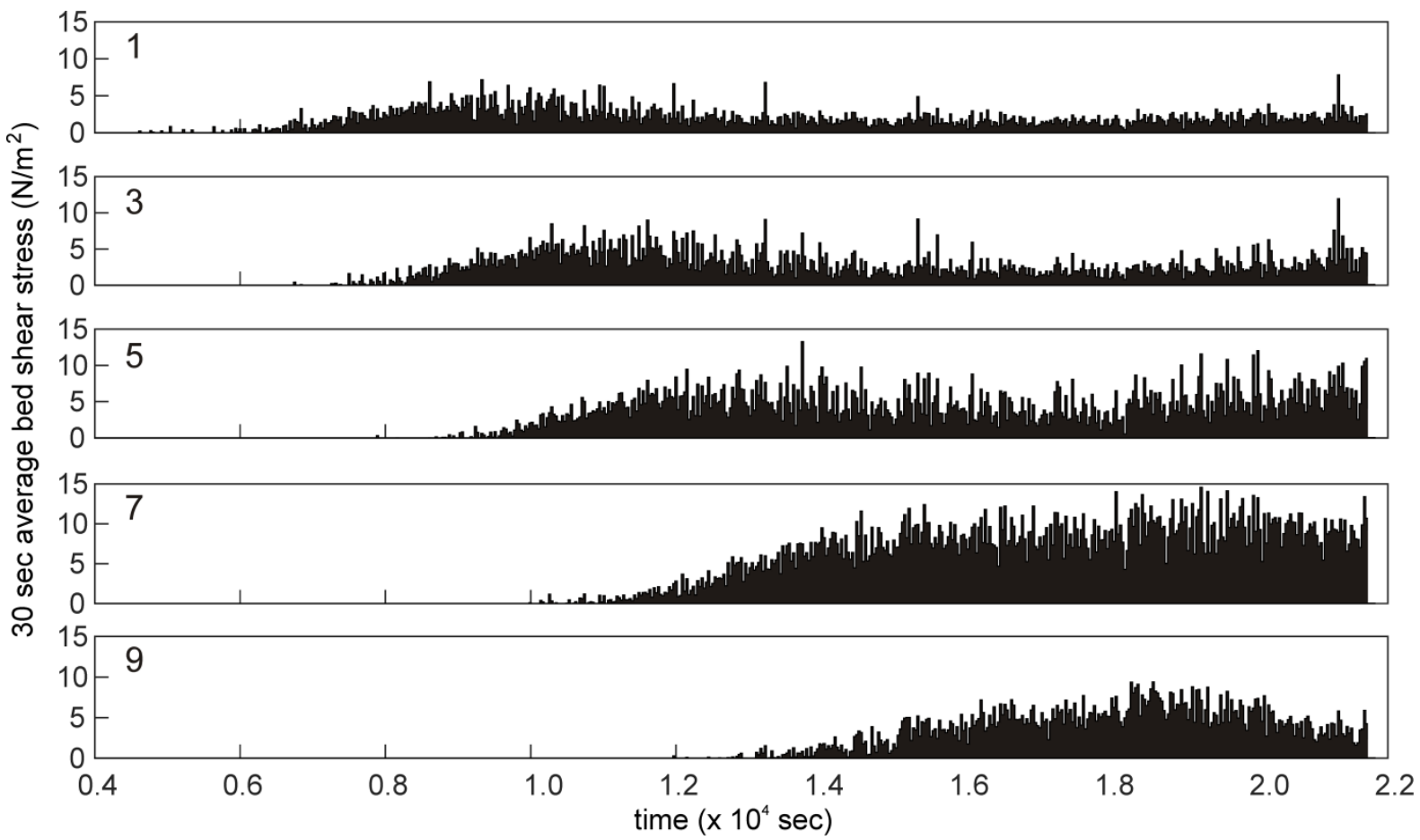

356 Figure 8: Instantaneous bed shear stress time-series derived from cross-shore velocity data 357 (Eq. 1) extracted at five cross-shore locations shown for $\mathrm{S3}_{6}$. 


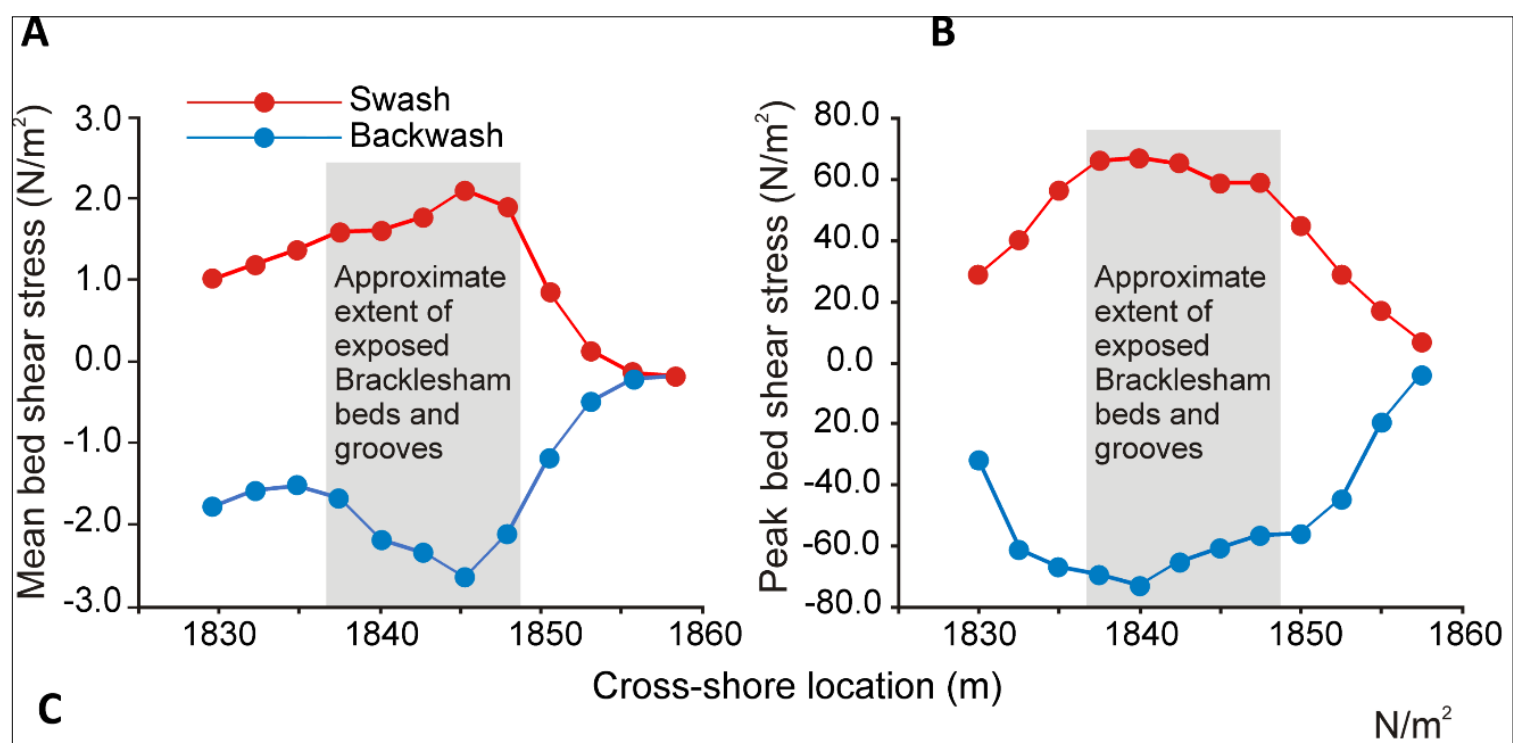

359 The mean bed shear stress averaged over approximately 6 hours, $\bar{\tau}$, and peak bed shear

360 stress, $\tau_{\max }$, values at the XBeach-G cross-shore data extraction locations between $X=1830$

$361 \mathrm{~m}$ and $X=1857.5 \mathrm{~m}$ are shown in Fig. 9 . The mean bed shear stresses peak in the upper one

362 third of the groove zone whilst the peak bed shear stresses peak in the lower third of the 363 zone. 
Figure 9: XBeach-G derived cross-shore distribution of bed shear stress for swash and backwash events over a 30 minute period: (A) mean values, and (B) peak instantaneous values. Sign of values indicates onshore (+) or offshore (-). C) XBeach-G derived temporal and cross-shore distributions of: (a) combined swash and backwash bed shear stress, (b) swashonly bed shear stress, and (c) backwash-only bed shear stress event.

The temporal and spatial distribution of predicted bed shear stress for run $\mathrm{S} 3_{6}$ at all 12 cross-shore locations (Fig. 7B) is shown (Fig. 9C) for the total bed shear stress (combined swash and backwash events) and for swash and backwash events separately.

\subsection{Groove morphology}

There was no discernible variation in groove morphology attributable to differences in the 
grooves increases down slope, as the spacing of the troughs declines in the same direction

(Fig. 10B; Table 3). Some grooves extend the full height of the beach face (e.g. Fig 6).

397 Locally, bifurcations in grooves exist and they face both up-slope and down-slope. A few grooves terminate downslope before the base is reached, but generally short, closelyspaced grooves exist on the lower beach face (Fig. 10). The up-slope terminations of the grooves are usually abrupt (as seen in the bottom left of Fig. 6 and the top left of Fig. 10) with a planar sandstone surface further up-slope close to the margin of the stripped beach shingle. Importantly, with respect to development of a model for groove development, the abrupt up-slope deep groove terminations occur between $x=1 \mathrm{~m}$ and $x \sim 0 \mathrm{~m}$ (Fig. 10). The groove depth initially shows some increase, before systematically decreasing down slope along with a similarly decreasing standard deviation of groove depths (Fig. 10C). The down slope terminations to the depths of grooves are either at the interface with the offshore sand (Fig. 10C) or the groove depths become insignificant close to that interface. The exact control on the position of the down slope terminations is unclear but may relate to the closure depth (Bray \& Hooke, 1997), the point seaward of which wave action is not able to erode the bed.

The plan view development of the bifurcating grooves is a space-filling adjustment in apparent response to the wave climate. These observations are consistent with Allen (1982; pp 43-46; Allen, 1987) who noted down slope reduction in groove depths and illustrated downslope decrease in spacing. Dżułyński \& Walton (1965) noted bifurcation in grooves and ridges formed beneath experimental sheet flow. There are no prior published data for beach face groove spacings, but Gorycki (1973) noted that the further up the beach the greater the spacing of beach cusps. Hughes and Turner (1999) attributed this increase in cusp spacing to wave dissipation on the steeper beach face at higher stages of the tide. Thus, utilising the same arguments as for cusps, the interpretation is that the variation in swash energy dissipation across the beach face at Medmerry mediates both the depth and the spacing of the grooves. This hypothesis is considered in section 4.1. 

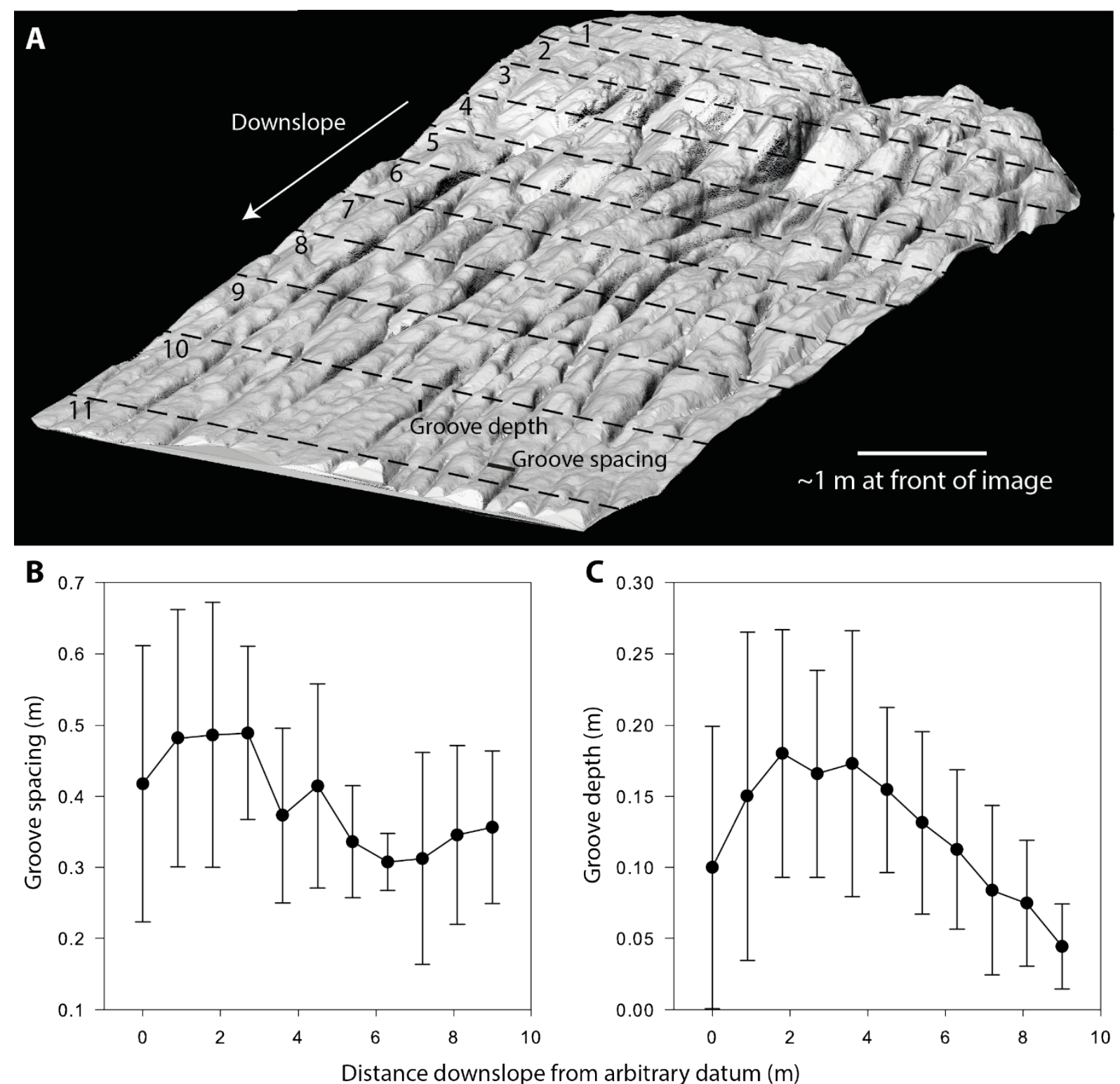

Figure 10: A) Oblique view of grooves looking from offshore to onshore showing the

424 locations of the evenly spaced (at $0.9 \mathrm{~m}$ ) profiles used to extract groove metrics of $B$ ) mean 425 spacing and C) mean depth. Error bars on B and C represent the standard deviation around 426 the mean.

\section{$4 \quad$ Discussion}

429 The interpretation of the results, in the context of the existing literature, is that the

430 formation mechanisms of the grooves may be related to erosive swash zone flows. Storm-

431 related waves, such as at Medmerry, which stripped the shingle from the beach, are 
evidently destructive and so the strong backwash likely would dominate over swash processes in the formation of the Medmerry grooves, either today or in former time, as shown from the wave simulations. Consequently, a conceptual model for swash-zone control on groove formation is explored below.

\subsection{Theoretical framework for groove formation}

was Above it was hypothesised that groove morphology reflects the beach face waveinduced sheet flow processes within the swash zone. As noted above, fluid stressing alone in high velocity flows can erode soft sandy rocks, but deep scour of compacted formations likely is aided by abrasion by swash zone bedload (Kamphuis, 1990) as well as fluid stressing.

Once small grooves form, the evolving bathymetry must increasingly constrain the local erosive flow within the grooves (Pollard et al., 1996; Whitehouse et al., 2000; Franca \& 444 Lemmin, 2006), thus 'locking' grooves into place where they can grow bigger. Given that the grooves are formed in near-homogeneous, weakly cemented sedimentary rock, the change in form across the beach face should be related to the hydraulic climate as is discussed below.

448 Landward of the wave break point, the swash velocity is driven primarily by near-shore 449 forcing conditions, beach roughness and slope. The backwash velocity is controlled 450 primarily by gravity, beach roughness and any offshore pressure gradients (Inch et al., 451 2015). Reduction in velocity, Reynolds numbers, and turbulent shear stresses occurs 452 landwards due to surge up the beach, but the same parameter values increase down the 453 beach face with the backwash (Inch et al., 2015). As a result of the interaction of the swash 454 with the backwash a peak in bed shear stress is anticipated at a location on the beach face 455 due to the peak in turbulence generated in the swash:backwash interaction as observed in 456 the wave simulations (Fig. 9).

\subsection{Cross-beach flow structure and groove depth}


459 Both the swash and the backwash cause erosion of the sandstone, and so the combined

460 effects of backwash meeting the swash flow needs consideration. Bakhtyar et al. (2009) 461 numerically modelled experimental data (Baldock et al., 1997; Shin \& Cox, 2006) for swash zone processes on steep profiles $(S=0.10)$ that typify shingle beach faces. Both experiments and numerical simulation demonstrated similar cross-beach swash behaviour. The wave height decreases rapidly landward across the beach whereas the set-up increases up the beach face. Significantly, both the backwash velocity and the turbulent kinetic energy (TKE) peak about $2 / 3$ of the way up the beach with rapid decline at higher elevations (Govender et al., 2004), with the highest TKE values occurring close to the bed (Bakhtyar et al., 2009). These TKE results are important with respect to explaining the abrupt up-slope terminations to deep grooves and the steady reduction in the groove depths down the beach face (Fig. 10) as TKE is directly related to the near-bed shear stress as shown below. Specifically, the peak in TKE is due to the backwash meeting the incoming swash (Shin \& Cox, 2006; Bakhtyar et al., 2009). Swash zone TKE, or $\bar{\tau}$, is the forcing mechanism for bed erosion as is explained below. The time-averaged total shear stress $\bar{r}=\tau$ ' $+\tau$ ', where $\tau$ ' is the form drag component and $\tau$ ' ' is the skin drag component, is proportional to the turbulent kinetic energy (TKE) at a given height $z$ close to the bed:

$$
\bar{\tau}_{\mathrm{TKE}}=\omega \rho \mathrm{TKE} .
$$

Here $\omega$ is a constant 0.19 (Soulsby \& Humphrey, 1990), in which case for a plane bed with little form resistance the bed erosion rate, $T\left(\mathrm{~kg} \mathrm{~m}^{-2} \mathrm{~s}^{-1}\right)$, can be considered (Huang, 2010) to vary in direct proportion to values of the near-bed shear stress, $\tau$ ' ' $\left(\mathrm{N} \mathrm{m}^{-2}\right)$. So for a flat consolidated sandstone bed, $\tau$ ' may be neglected such that $\bar{\tau} \rightarrow \tau$ ', Following Ariathurai \& Arulanandan (1978), the general relationship for the erosion rate $(T)$ of a compact bed is (Thorn \& Parsons, 1980):

$$
\mathrm{T}=\mathrm{k}_{\mathrm{d}}\left(\tau^{\prime \prime}-\tau_{0}^{\prime \prime}\right) \text {, if } \tau^{\prime \prime}>\tau_{0}{ }^{\prime}
$$

where $\tau_{0}$ ' is a threshold value of $\tau$ " 'for zero erosion, and $k_{d}\left(\mathrm{~s} \mathrm{~m}^{-1}\right)$ is a constant that depends on the material properties of the bed. 
487 The trend in the observed depths of the grooves (Fig. 10) is reproduced together with

488 theoretical estimates of erosion rates (Equation 3) for the modelled maximum shear stress

489 distributions across the swash zone, given a threshold of $10 \mathrm{~N} \mathrm{~m}^{-2}$ (Fig. 11). The constant $k_{d}$ 490 in equation 3 is not known for the sandstone but should assume a value of the order of $1 \mathrm{x}$ $49110^{-7}$ (Dean \& Dalrymple, 2002) and this value is used here as a scalar. The results indicate 492 that erosion is likely maximised at a point $1 / 3$ up the beach face, which agrees with the 493 variation in groove depth that reach minimal values in the lower beach face. Although the 494 ridges between grooves must also be declining in height due to erosion, the presence of 495 grooves demonstrates that groove erosion is more rapid that ridge erosion. The current 496 results differ in the position of maximum erosion when compared with flume experiments 497 conducted on cohesive-sediment beach-profiles (Skafel \& Bishop, 1994; Skafel, 1995), 498 wherein the maximum rate of erosion within the swash zone occurred typically $2 / 3$ of the 499 distance up the beach face; otherwise the results are comparable. Regardless, deep 500 grooves are best preserved in the upper beach face, above which the backswash shear 501 stress drops to below $01 \mathrm{~N} \mathrm{~m}^{-2}$, the theoretical erosion drops rapidly (up-slope of $x=$ $5021850 \mathrm{~m})$, and groove depth tends to zero. 


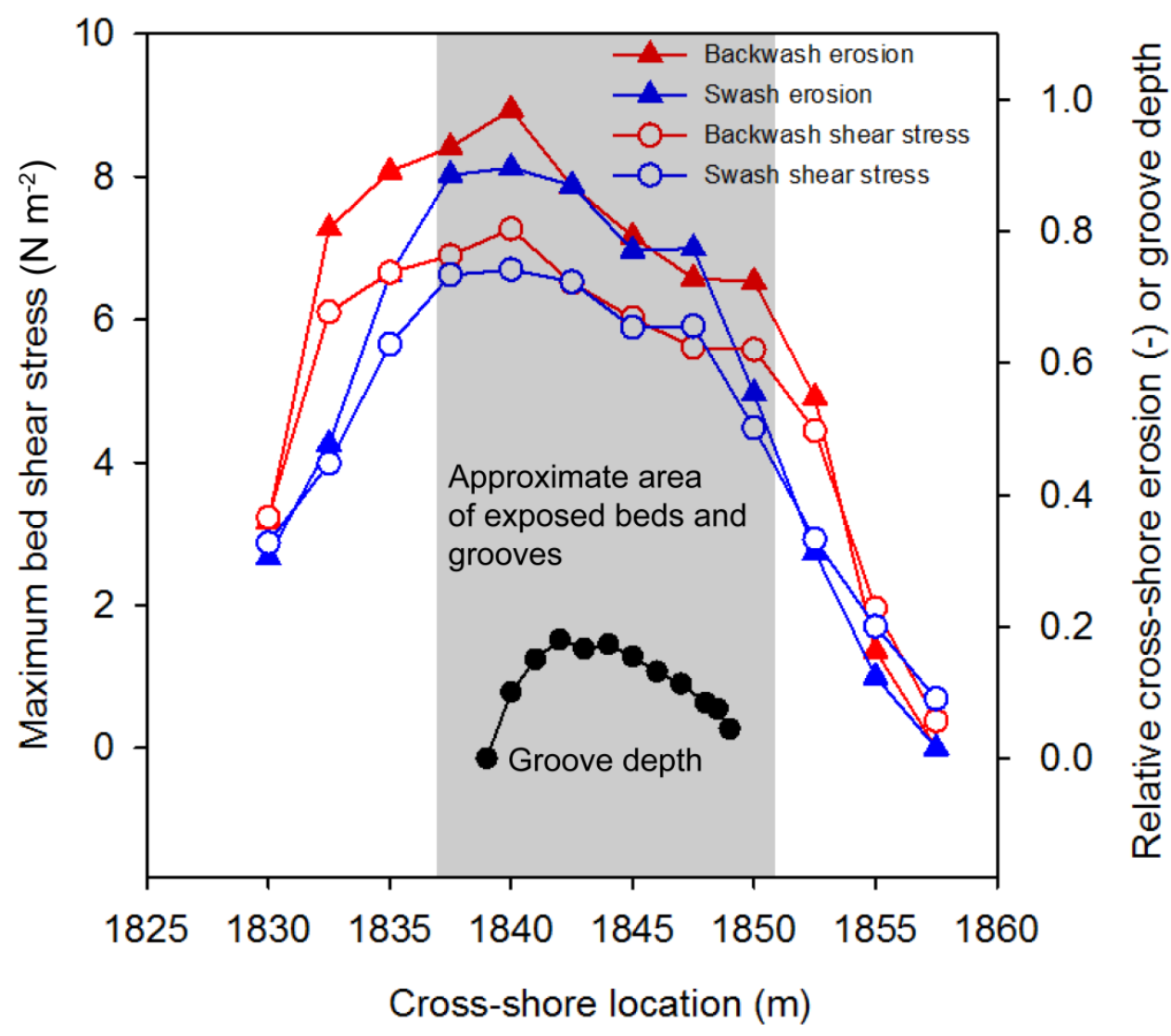

Figure 11: Theoretical cross-shore bed relative erosion rates due to peak stress distributions.

The erosion rates are normalized by the smallest rate values and the shear stress values are normalized by dividing by $10 \mathrm{~N} \mathrm{~m}^{-2}$, such that curves plot in close proximity on the $y$-axis for

\subsection{Alongshore flow structure and groove spacing}

512 Previously, two mechanistic theories have been applied to explain periodic, closely-spaced,

513 erosional topography on storm-effected sandy steep shorelines. Hughes and Turner (1999)

514 argued that incipient topographic lows in the beach profile are amplified by attracting and 515 accelerating swash such that the depressions are enhanced. Alternately, Gorycki (1973; see 516 also Dżułyński \& Walton 1965, p. 212) argued that the front of swash flow inherently forms 517 periodic salients of faster and slower flow, which lead to differential erosion and deposition 518 along the beach face that reflects the initial salient structure. Model 1 (Hughes \& Turner, 519 1999) does not explain the periodic spacing of grooves alongshore, but topographic forcing 
clearly can assist in constraining Model 2 (Gorycki, 1973) salient flow structures. This argument for spanwise flow structure controlling the spacing of topographic lows is similar to the argument for streaky shore-normal vortex trains (Allen, 1970) controlling the periodic spacing of backwash parting lineation (Allen, 1964; Otvos, 1999; Pepper, 1996; Boggs, 2011) on sandy beaches. Application of both Models 1 and 2 to the present problem requires that initial random defects in the bed roughness or velocity field will mutually adjust through erosion to produce shore-normal erosional grooves. A more recent kinematic approach, without recourse to the detailed hydrodynamics of the swash zone, unifies Models 1 and 2 and argues that beach face patterns are due to self-organization of the sediment surface due to the local flow crossing a plane bed (Werner \& Fink, 1993). Such self-organised patterns may be related to forcing by wave height and storm duration, but such kinematic models do not account for specific bedform spacings (Calvete et al., 2007). Nevertheless, it is possible to obtain some insight into the flow controls on any self-organised pattern. In contrast to section 4.2 above, both swash and backwash flows can be considered individually as unidirectional flows with unsteady boundary layers above a plane bed. So, beach face flow often has been modelled simply using the quadratic stress law, sometimes with different friction factors (Hughes \& Baldock, 2004; Inch et al., 2015).

The simple arguments above imply that consideration of basic scaling relationships, such as between depth of swash zone flow $(H)$, bed roughness $\left(k_{s}\right)$ and swash zone velocity $(U)$, could provide partial explanation for the development of flow streakiness (and by corollary the presence of grooves), even if the detailed planview hydrodynamics are unknown. In numerical simulations, Piomelli \& Balaras (2002) noted that streaks were best developed close to the bed. In experimental high-speed shallow flows over a plane bed, Cooper \& Tait (2008) noted the spacing of alternating high and low longitudinal velocity streaks close to the bed depended on flow depth $(H)$, a pattern Mohajeri et al. (2015) ascribe to cellular secondary currents generating low and high momentum streaks. The lateral spacing of streaks (Mohajeri et al., 2015) is typically 1.2 to $1.6 \mathrm{H}$ which, although less than those recorded by Kinoshita $(1967 ; 2 H)$ and Albayrak \& Lemmin $(2011 ; 1.85 H)$, is otherwise broadly comparable. Application of these scaling relationships to the observed average spacings $(\bar{B})$ of the Medmerry grooves $(\bar{B}=0.38 \mathrm{~m})$ indicates expected swash zone depths of between $0.19 \mathrm{~m}$ and $0.31 \mathrm{~m}$, consistent with modelled depths for the higher and more 
erosive breakers at Medmerry (Table 1). High velocity streaks are associated with downward motions and low velocity streaks with upward motions, and in very shallow flows $\left(H / k_{s} \sim 6\right)$ streak structure appears to extend throughout the flow depth (Mohajeri et al., 2015). Thus, given shallow Medmerry swash and backwash zone flows $\left(H / k_{s} \leqslant 5.85\right.$; see Camenen et al., 2008 for derivation of $k_{s}$ in oscillatory sheet flows above plane beds), streak structure would impact the bed. In broad flows over plane beds, this secondary circulation seems to be initiated by inevitable spatial heterogeneities in bed texture (Barros \& Christensen, 2014) in accord with mechanisms 1 and 2 above, but the spanwise streakiness structure is probably a self-organising emergent condition induced by any localised bed perturbation, as is explained below. Nevertheless, the distance over which the incident flow has to develop in order to develop distinct streak structure is unknown (Mohajeri et al. 2015), which implies a length scale (Reynolds number) control on the initiation of the self-organising process.

\subsection{A conceptual model for swash-zone control on groove formation}

The detailed planview flow structure within natural swash zones has yet to be defined. Nevertheless, the beach face flows, as discussed above, have characteristics similar to those recorded in laboratory experiments and numerical simulations of plane or curved, shallow, high-speed flow (Floryan \& Saric, 1982; Pollard et al., 1996; Wilhelm et al., 2003; Lanzerstorfer \& Kuhlmann, 2012a, b, c) where streakiness has been observed. Specifically, the backwash is an expanding high-velocity, high Reynolds number flow subject to perturbations above a plane or curvilinear bed, whereas the swash is a contracting and decelerating flow. Considerable interactions of swash with backwash from previous waves impose a distinct vertical structure to flow (Bakhtyar et al., 2009) that is conducive to flow uplift. Thus, it seems reasonable to ascribe streakiness in the backwash as the control on the spacing of the grooves observed at Medmerry, and potentially elsewhere. Groove spacing, as with streak spacing (Wilhelm et al., 2003), is almost certainly an emergent property of flow perturbations and no explanation for specific streak spacings exists. In 581 accord with other self-organising models of regularly spaced shore-line bedforms (e.g. Coco 
local wave-induced flow field but also is likely to be mediated by larger-scale topographic

584 controls of the specific shoreline.

585

\section{$5865 \quad$ Conclusions}

587 Regularly spaced shore-normal grooves cut into a soft sandstone beach face were 588 investigated after storm wind-waves stripped shingle from the beach face. The depths of 589 the grooves vary systematically across the shore, whilst the spacing of the grooves 590 alongshore is also somewhat regular. A qualitative model explaining groove formation and 591 morphology is presented, developed from detailed field measurements and quantitative 592 modelling of the formative wave-induced flows. Numerical modelling of the translation 593 from offshore waves to nearshore breaking waves provided realistic estimates of the swash zone parameters. Near-bed swash shear stresses (and resultant erosion intensity) are dome-shaped functions of distance across the beach face that match variation in the depths of the grooves. An explanation for the long-shore spacing of the grooves is that the regularity mimics quasi-regular long-shore streakiness of the swash zone flows. However, the exact spacing of streaks and grooves cannot be quantitatively determined as the specific spacings are likely a property, not only of the local flow attributes, but also of larger-scale morphological forcing which remains unknown. The latter will always be site specific. Thus, the specific spacing of grooves is an emergent, self-organizing, property of the specific hydrodynamic climate of any particular beach face.

\section{Acknowledgements}

605 Thanks are due to David Bone (Chichester) for provision of key literature on the 606 Bracklesham Beds. Gerd Masselink and Paul Myrow are thanked for insightful reviewers 607 that led to improvement of the presentation of the arguments.

\section{References}

610 Aigner, T, 1985, Storm Depositional Systems, Springer-Verlag, Berlin, 174pp. 
Albayrak, I., Lemmin, U., 2011, Secondary currents and corresponding surface velocity

612 patterns in a turbulent open-channel flow over a rough bed. Journal of Hydraulic

613 Engineering, 137, 1318-1334.

Aldiss, D.T. 2002. Geology of the Chichester and Bognor district. Sheet description of the

British Geological Survey, 1:50000 Series Sheet 317 and Sheet 332 (England and Wales).

Allen, J.R.L., 1964, Primary current lineation in the lower Old Red Sandstone (Devonian), Anglo-Welsh Basin. Sedimentology, 3, 89-108.

Allen, J.R.L., 1970, Physical Processes of Sedimentation, Allen \& Unwin, London.

Allen, J.R.L., 1982, Sedimentary Structures: their Character and Physical Basis, Vol II, Elsevier, Amsterdam, 663pp.

Allen, J.R.L., 1987, Late Flandrian shoreline oscillations in the Severn Estuary: The Rumney Formation at its type site (Cardiff Area). Philosophical Transactions of the Royal Society of London. Series B, 315, 157-184.

Ariathurai, R., Arulanandan, K., 1978, Erosion rates of cohesive soils: Journal of the Hydraulics Division of the American Society of Civil Engineers, 104, no. HY2, 279-283.

Bakhtyar, R., Barry, D.A., Yeganeh-Bakhtiary, A., Ghaheri, A., 2009, Numerical simulation of surf-swash zone motions and turbulent flow. Advances in Water Resources, 32, 250-263.

Baldock, T.E., Holmes, P., Horn, P., 1997, Low frequency swash motion induced by wave grouping. Coastal Engineering, 32, 197-222.

Barros, J.M., Christensen, K.T., 2014, Observations of turbulent secondary flows in a roughwall boundary layer. Journal of Fluid Mechanics, 748, R1, doi:10.1017/jfm.2014.218

Birkenmajer, K., 1958, Oriented flowage casts and marks in the Carpathian flysch and their relation to flutes and groove casts. Acta Geologica Polinica, 8: 117-144.

Beukes, N.J., 1996, Sole marks and combined-flow storm event beds in the Brixton Formation of the siliclastic Archean Witwatersrand supergroup, South Africa. Journal of Sedimentary Research, 66, 567-576.

Boggs, S. 2011, Principles of Sedimentology and Stratigraphy, $5^{\text {th }}$ Edition, pp 125-126, Pearson.

Bone, D.A., Tracey, S. 1996. Aerial photography and geological mapping of Bracklesham Bay, West Sussex. Tertiary Research, 16: 25-40.

Bradbury, A.P., Mason, T.E., 2014, Review of south coast beach response to wave conditions in the winter of 2013-2014. Report SR 01, Southeast Regional Coastal Monitoring 
Programme, Channel Coastal Observatory, National Oceanography Centre, Southampton, UK, 75pp.

Bray, M.J., Hooke, J.M., 1997, Prediction of soft-cliff retreat with accelerated sea-level rise. Journal of Coastal Research, 13, 453-467.

Camenen, B., Larson, M., Bayram, A., 2009, Equivalent roughness height for plane bed under oscillatory flow. Estuarine, Coastal and Shelf Science, 81, 409-422.

Carling, P.A. (2013) Subaqueous "yardangs": Analogs for aeolian yardang evolution. Journal of Geophysical Research, 118, 1-12.

Carling, PA, Williams, JJ, Croudace, IW, Amos, CL, 2009, Formation of mud ridge and runnels in the intertidal zone of the Severn Estuary, UK. Continental Shelf Research, 29: 1913-1926.

Calvete, D., Coco, G., Falque, A., Dodd, N., 2007, (Un)predictability in rip channel systems. Geophysical Research Letters, 34, L05605, doi:10.1029/2006GL028162

Coco, G., Murray, A.B., 2007, Patterns in the sand: From forcing templates to selforganization. Geomorphology, 91, 271-290.

Cooper, J., Tait, S., 2008, The spatial organisation of time-averaged steramwise velocity and its correlation with the surface topography of water-worked shingle beds. Acta Geophysica, 56, 614-641.

Curry, D., King, A.D., King, C. \& Stinton, F.C. 1977. The Bracklesham Beds (Eocene) of Bracklesham Bay and Selsey, Sussex. Proceedings of the Geologists' Association, 88: 243254.

Daley, B. 1999. Hampshire Basin: mainland localities. In British Tertiary Stratigraphy, Geological Conservation Review Series No. 15, (eds. B. Daley and P. Balson). Joint Nature Conservation Committee, Peterborough, pp. 159-212.

Dean, R.G., Dalrymple, R.A., 2002, Coastal Processes: with Engineering Applications. Cambridge University Press, Cambridge, UK, 475pp.

Deltares, 2015, XBeach Manual, Unesco-IHE, Deltares and Delft University of Technology, $135 \mathrm{pp}$.

Duke W.L. 1990, Geostrophic circulation or shallow marine turbidity currents? The dilemma of paleoflow patterns in storm-influenced prograding shoreline systems. Journal of Sedimentary Petrology, 60, 870-883.

Dżułyński, S., Walton, E.K., 1965, Sedimentary Features of Flysch and Greywackes. Developments in Sedimentology 7, Elsevier, Amsterdam, 274pp. 
Edwards, R.A., Freshney, E.C. 1987. Lithostratigraphical classification of the Hampshire Basin

Palaeogene Deposits (Reading Formation to Headon Formation). Tertiary Research, 8: 43-

686 73.

Evans, O.F., 1938. Classification and origin of beach cusps. Journal of Geology, 46, 615-627.

Floryan, J.M., Saric, W.S., 1982, Stability of Görtler vortices in boundary layers. AIAA Journal, 20, 316-324.

Franca, M.J., Lemmin, U., 2006, Cross-section periodicity of turbulent gravel-bed river flows. In: Parker, G., García, M.H. (Eds.), River, Coastal and Estuarine Morphodynamics. Taylor and Francis, New York, pp. 203-210.

Gallop, S.L., Bryan, K.R., Coco, G., Stephens, S.A., 2011, Storm-driven changes in rip channel patterns on an embayed beach. Geomorphology, 127, 179-188.

Gorycki, M.A., 1973, Sheetflood structure: mechanism of beach cusp formation and related phenomena. Journal of Geology, 81, 109-117.

Govender, K., Mocke, G.P., Alport, M.J., 2004, Dissipation of isotropic turbulence and lengthscale measurements through the wave roller in laboratory spilling waves. Journal of Geophysical Research, 109, C08018, doi:10.1029/2003JC002233

Groba, von E., 1959, Geologische unterwasserkartierung im litoral der deutschen Ostseeküste, Acta Hydrophysica, 5, 163-200.

Hawkes, D.D., 1962, Erosion of tidal flats near Georgetown, British Guiana. Nature, 196, 128130.

Hiscott, R.N., 1982, Tidal deposits of the Lower Cambrian Random Formation, eastern Newfoundland: facies and paleoenvironments. Canadian Journal of Earth Sciences, 19, 20282042.Huang, H.Q., 2010, Reformulation of the bed load equation of Meyer-Peter and Müller in light of the linearity theory for alluvial channel flow. Water Resources Research, 46, W09533, doi: 10.1029/2009WR008974

Hughes, M., Turner, I., 1999, The Beachface, Chapter 5 In: Short, A.D. (ed) Handbook of Beach and Shoreface Morphodynamics, Wiley, Chichester, 379pp.

Hughes, M.G., Baldock, T.E., 2004, Eulerian flow velocities in the swash zone: Field data and model predictions. Journal of Geophysical Research, 109, C08009, doi:10.1029/2003JC002213

Inch, K., Masselink, G., Puleo, J.A., Russell, P., Conley, D.C., 2015, Vertical structure of nearbed cross-shore flow velocities in the swash zone of a dissipative beach. Continental Shelf Research, 101: 98-108. 
Kamphuis, J. W., 1990. Littoral sediment transport rate. In: Proceedings of 22nd Coastal Engineering Conference. New York: American Society of Civil Engineers, pp 2402-2415.

Kinosjita, R., 1967, An analysis of the movement of flood waters by aerial photography concerning characteristics of turbulence and surface flow. Journal of the Japanese Society of Photogrammetry, 6, 1-17. (in Japanese).

King, C. 1996. The stratigraphy of the Bracklesham Group of Bracklesham Bay and Selsey (West Sussex, England): an update 1977 - 1995. Tertiary Research, 16: 15-23.

Lanzerstorfer, D., Kuhlmann, H.C., 2012a, Global stability of multiple solutions in plane sudden-expansion flow. Journal of Fluid Mechanics 702, 378-402.

Lanzerstorfer, D., Kuhlmann, H.C., 2012b, Global stability of the two-dimensional flow over a backward-facing step. Journal of Fluid Mechanics 693, 1-27.

Lanzerstorfer D., Kuhlmann H.C., 2012c. Three-dimensional instability of the flow over a forward-facing step. Journal of Fluid Mechanics 695, 390-404

Masselink, G., Scott, T., Conley, D., Davidson, M., Russell, P., 2015. Regional variability in Atlantic storm response along the southwest coast of England. Proceedings Coastal Sediments, ASCE, San Diego, USA.

McCall, R., Masselink, G., Poate, T., Roelvink, J., Almeida, L., Davidson, M., Russell, P., 2014. Modelling storm hydrodynamics on gravel beaches with XBeach-G. Coastal Engineering, 91, 231-250.

McCall, R., Masselink, G., Poate, T., Roelvink, J., Almeida, L., 2015. Modelling the morphodynamics of gravel beaches during storms with XBeach-G. Coastal Engineering, 103, 52-66.

McKie, T., 1994. Geostrophic versus friction-dominated storm flow: paleocurrent evidence from the Late Permian Brotherton Formation, England. Sedimentary Geology, 93, 73-84.

Mohajeri, S.H., Grizzi, S., Righetti, M., Romano, G.P., Nikora, V., 2015, The structure of gravel-bed flow with intermediate submergence: a laboratory study. Water Resources Research, doi: 10.1002/2015WR017272

Myrow, P.M., 1992, Pot and gutter casts from the Chapel Island Formation, southeast Newfoundland: Journal of Sedimentary Petrology, 62, 992-1007.

Myrow, P.M., 1994, Pot and gutter casts from the Chapel Island Formation, southeast Newfoundland - reply. Journal of Sedimentary Petrology, 64, 706-709.

Otvos, EG, 1999, Rain-induced beach processes; landforms of ground water sapping and surface runoff. Journal of Coastal Research, 15: 1040-1054. 
Owen, M.W., 1975, Erosion of Avonmouth mud. Report No INT 150, Hydraulics Research

762 Station, Wallingford, UK, 27pp.

Pepper, D.A., 1996, The occurrence, morphology, and sedimentology of sediment streaks in the swash zone. Unpublished PhD thesis, University of Windsor, Ontario, 63pp. **

Plint, A.G., 1988, Global eustacy and the Eocene sequence in the Hampshire Basin, England. Basin Research, 1, 11-22.

Plint, A.G., 1991, High-frequency relative sea-level oscillations in Upper Cretaceous shelf clastics of the Alberta foreland basin: possible evidence for a glacio-eustatic control? Special. Publication International Association of Sedimentologist, 12: 409-428.

Plint, G., Cheadle, B.A., 2015, Reply to the Discussion by Schieber on "Mud dispersal across a Cretaceous prodelta: Storm-generated, wave-enhanced sediment gravity flows inferred from mudstone microtexture and microfacies", Sedimentology, 62, 394-400.

Plint, A.G., Norris, B., 1991, Anatomy of a ramp margin sequence: facies successions, paleogeography, and sediment dispersal patterns in the Muskiki and Marshybank formations, Alberta Foreland Basin. Bulletin of Canadian Petroleum Geology, 39: 18-42.

Plint, A.G., Nummendal, D., 2000, The falling stage systems tract: recognition and importance in sequence stratigraphic analysis. Pp. 1-17 In: D. Hutt and R.L. Gawthorpe (eds.) Sedimentary Responses to Forced Regressions. Special Publication 172, The Geological Society of London.

Pollard, A., Wakarini, N., Shaw, J., 1996. Genesis and morphology of erosional shapes associated with turbulent flow over a forward-facing step. In, P.J. Ashworth (Ed.), Coherent Flow Structures in Open Channels, pp. 249-265. Wiley, New York.

Reid, C., 1892. The Pleistocene deposits of the Sussex coast, and their equivalents in other districts. Quarterly Journal of the Geological Society, 48, 344-364.

Roelvink, J.A., Reniers, A., van Dongeren, A., van Thiel De Vries, Lescinski, J., McCall, R., 2010, XBeach Model Description and Manual, Deltares, Delft, The Netherlands.

Roelvink, D., Reniers, A., van Dongeren, A., Van Thiel de Vries, J., McCall, R., Lescinski, J., 2009, Modelling storm impacts on beaches, dunes and barrier islands. Coastal Engineering, 56: 1133-1152.

Seibold, E., 1963, Geological investigation of nearshore sand-transport examples of methods and problems from the Baltic and North Seas. Progress in Oceanography, 1, 3-70.

Shank, J.A., Plint, A.G., 2013, Allostratigraphy of the Upper Cretaceous Cardium Formation in subsurface and outcrop in southern Alberta, and correlation to equivalent strata in northwestern Montana. Bulletin of Canadian Petroleum Geology, 61: 1-40. 
805

806

807

808

809

810

811

812

813

814

815

816

817

818

819

820

821

822

823

824

825

826

827

828

829

830

831

832

833

834

Shin, S., Cox, D., 2006, Laboratory observations of inner surf and swash-zone hydrodynamics on a steep slope. Continental Shelf Research, 26, 561-573.

Skafel, M.G., 1995, Laboratory measurement of nearshore velocities and erosion of cohesive sediment (till) shorelines. Coastal Engineering, 24, 343-349.

Skafel, M.G., Bishop, C.T., Flume experiments on the erosion of till shorelines by waves.

Coastal Engineering, 23, 329-348.

Soulsby, R. L., J. D. Humphery, 1990, Field observations of wave current interaction at the sea bed, in Water Wave Kinematics, (eds A. Torum, O. T. Gunmestad, pp. 413-428, Springer, New York.

Soulsby, R., 1997. Dynamics of marine sands: a manual for practical applications. Thomas Telford. 249pp.

Sunamura, T., and Y. Matsukura (2006), Laboratory test of bedrock abrasion by sedimententrained water flow: A relationship between abrasion rate and bedrock strength, Transactions of the Japanese Geomorphological Union, 27, 85-94.

The Met. Office, 2014, The Recent Storms and Floods in the UK., Meteorological Office, Exeter, 28pp.

Thorn, M.F., Parsons, J.G., 1980, Erosion of cohesive sediments in estuaries: an engineering guide. pp 349-358 In: Third International Symposium on Dredging Technology, H.J. Stephens (ed.), Bordeaux, France.

Werner, B.T., Fink, T.M., 1993, Beach cusps as self-organized patterns. Science, 260, 968971.

835 Whitehouse, R.J.S., Bassoullet, P., Dyer, K.R., Mitchener, H.J., Roberts, W., 2000. The 836 influence of bedforms on flow and sediment transport over intertidal mudflats. Continental 837 Shelf Research, 20, 1099-1124.

838 Whittacker, J.H., 1973, "Gutter casts". A new name for scour-and-fill structures: with 839 examples from the Llandoverian of Ringerike and Malmöya, southern Norway. Norsk geol. 840 Tidesskrift, 53: 403-417.

841 Wilhelm, D., Hartel, C., Kleiser, L., 2003. Computational analysis of two-dimensional-three842 dimensional transition in a forward-facing step flow. Journal of Fluid Mechanics 489, 1-27.

843 Zijlema,M., Stelling, G., Smit, P., 2011. Swash: An operational public domain code for 844 simulating wave fields and rapidly varied flows in coastal waters. Coastal Engineering, 58, 845 992-1012. 